\title{
Succession on tin-mined land in Bangka Island
}

\author{
E. Nurtjahya ${ }^{1}$, D. Setiadi², E. Guhardja ${ }^{2}$, Muhadiono $^{2}$, Y. Setiadi ${ }^{3}$
}

Key words

Bangka

succession

tin-mined land

\begin{abstract}
A quantitative study of floristic composition and vegetation structure was conducted at Bangka Island Indonesia. Six different vegetation types were chosen, riparian forest, abandoned farmland, and natural regeneration of tin-mined lands of different ages: 0 and barren, 7, 11 and 38 years' old tin-mined land. The seedling composition of the oldest tin-mined land was less than $2 \%$ similar to that of a riparian forest. Natural regeneration on 7-year old tin-mined land began with herb species belonging to Cyperaceae, Poaceae, and Melastomaceae; followed by herb species belonging to Asteraceae and Poaceae on 11-year old; then by Poaceae and shrub species of Myrtaceae on 38-year old tin-mined land. Older tin-mined land tended to have less sand, higher nutrients and cation-exchange capacity. The phosphate solubilizing bacteria showed a gradual increase along with the more newly abandoned tin-mined land but decreased in barren tin-mined land, while the number of arbuscular mycorrhizal fungal spores showed the opposite.
\end{abstract}

Published on 30 October 2009

\section{INTRODUCTION}

Tin deposits in Bangka Island have been exploited for about a hundred years with increased intensity during the Dutch colonial period. Bangka is the largest tin producing island in Indonesia, contributing $40 \%$ of world demand of tin (ASTIRA 2005). Tin mining leaves disturbed land and ex-tin mining ponds ('kolong'), damages natural drainage and habitats, and causes pollution. Reliance on natural succession to restore sand tin tailings without any human intervention requires a long time, during which the tin tailings remain economically barren (Mitchell 1959, Ang 1994, Elfis 1998).

To obtain a more detailed picture of succession on tin-mined land, especially sand tin tailings in Bangka Island, floristic and species composition, soil properties, and soil flora and fauna of different ages of natural regeneration of tin-mined sites was needed. This study will be useful for the re-establishment of diverse native forests. Dominant among the species planted in Bangka since 1993 are a number of exotic species (Nurtjahya 2001), but ecological caution suggests it is unwise to continue to rely on such a limited species mix for all future rehabilitation efforts (Lamb \& Tomlinson 1994). While there is no list of local tree species as candidates for revegetating tin-mined land in Bangka Island, some scholars, however, have suggested some local species (Sambas \& Suhardjono 1995, Van Steenis in Whitten et al. 2000). Other suggested sources for species that are suitable for revegetating sand tin tailings are Padang-vegetation (Van Steenis 1932), regarded as degraded heath forest (Whitten et al. 2000); coastal mixed forest with Barringtonia formation (Whitten et al. 2000), and heath forest (MacKinnon et al. 1996).

The aim of this study was to understand the succession on tin-mined land in Bangka Island, in order to develop better criteria for the selection and identification of local species with the potential to revegetate these lands.

1 Postgraduate student at Institut Pertanian Bogor, Program Studi Biologi, Universitas Bangka Belitung, Jalan Diponegoro No. 16, Sungailiat 33215, Bangka Belitung, Indonesia; e-mail: eddy_nurtjahya@yahoo.com.

2 Departemen Biologi, Institut Pertanian Bogor, Bogor, Indonesia.

${ }^{3}$ Laboratorium Bioteknologi Hutan dan Lingkungan, Pusat Penelitian Sumberdaya Hayati dan Bioteknologi, Institut Pertanian Bogor, Bogor, Indonesia.

\section{METHODS}

\section{Study sites}

A quantitative ecological study of tin tailings in the Bangka Regency, Province of Bangka Belitung, Indonesia was carried out from May 2004 to November 2005 on six different types of vegetation (Fig. 1, 2). The study involved field surveys, interviewing locals, and consulting the tin mining map (PT Tambang Timah 2004), and land use and land system maps (Bakosurtanal 1986 , Widagdo et al. 1990). Study plots were a 13 ha riparian forest at Sempan $\left(01^{\circ} 53^{\prime} 38.5^{\prime \prime S} 105^{\circ} 58^{\prime} 14.5^{\prime \prime E}\right)$, a 4 -year old 1.6 ha abandoned farmland ('ladang' at Sempan), and natural regeneration of tin-mined lands of different ages: 0-year old 2 ha barren tin-mined land at Riding Panjang (01'59'53.4"S $\left.106^{\circ} 06^{\prime} 45.3^{\prime \prime E}\right), 7$-year old 0.5 ha land at Sempan, 11-year old 0.6 ha at Gunung Muda $\left(01^{\circ} 37^{\prime} 0.01^{\prime \prime S} 105^{\circ} 54^{\prime} 47.9^{\prime \prime E}\right)$, and

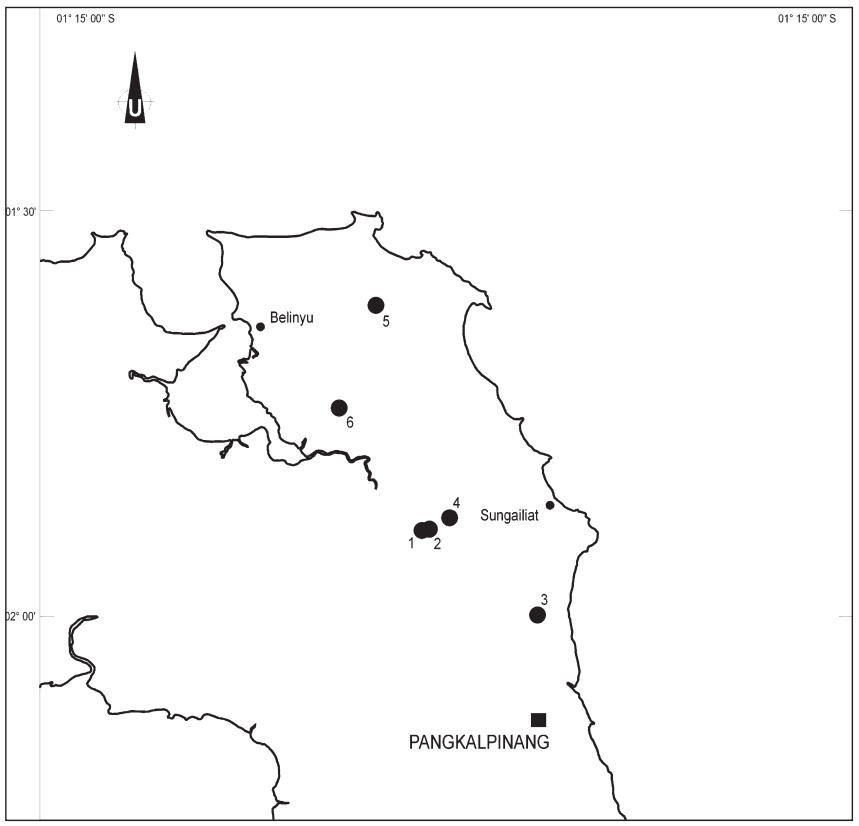

Fig. 1 Study sites in Bangka Island: (1) riparian forest; (2) abandoned farmed-land; (3) 0-year old barren tin-mined land; (4) 7-year old tin-mined land; (5) 11-year old tin-mined land; (6) 38-year old tin-mined land. 
38-year old 2 ha at Riau $\left(01^{\circ} 44^{\prime} 33.8^{\prime \prime S} 105^{\circ} 51^{\prime} 66.4 " \mathrm{E}\right)$. All plots located are below $50 \mathrm{~m}$ asl.

\section{Data collection and analysis}

Soil properties, arbuscular mycorrhizal fungi, and phosphate solubilizing bacteria

Soil was sampled at $0-20 \mathrm{~cm}$ and $20-40 \mathrm{~cm}$ depth using an $8 \mathrm{~cm}$ auger. Diagonal composite (Setyorini et al. 2003) sample of nine subsamples and single replicate were analyzed. A composite of eight rhizosphere points of $500 \mathrm{~g}$ samples for phosphate solubilizing bacteria (PSB) and arbuscular mycorrhizal fungi (AMF) spores, which were taken at $0-10 \mathrm{~cm}$ and 10-20 cm depth and three replicates, were collected using a modified CSM-BGBD Project protocol (2004) under three highest important value index (IVI) domination at each site. Fungal spores were recovered by wet sieving and decanting (Gadermann \& Nicolson 1963), and genera were identified (Schenck \& Perez 1988; INVAM). Soil solution was seeded in the surface of Picovskaya agar and colonies showing transparent halos around them were counted, and re-isolated and maintained in nutrient agar.

\section{Vegetation analysis}

A minimum study plot size of 0.2 ha per study site was determined on basis of the species-area curve (Setiadi \& Muhadiono 2001). The study was conducted on 20 contiguous plots of 10 by $10 \mathrm{~m}$ at each of the study sites using the modified quadrat sampling technique of Oosting 1956 (Soerianegara \& Indrawan
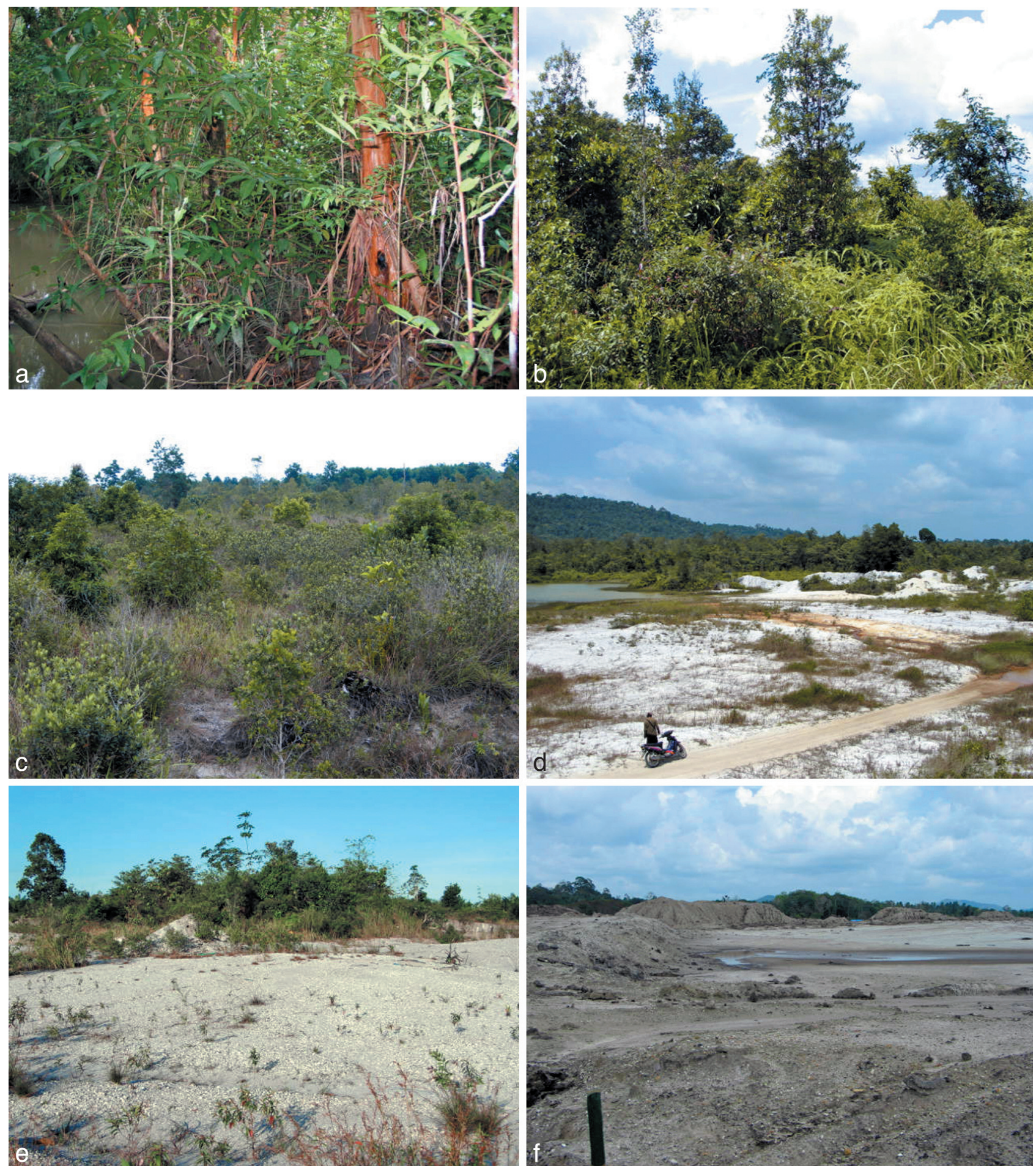

Fig. 2 Vegetation aspects of study sites. a. Riparian forest; b. abandoned farmed-land; c. 38-year old tin-mined land; d. 11-year old tin-mined land; e. 7-year old tin-mined land; f. 0-year old barren tin-mined land. Photos E. Nurtjahya. 
1995). Quadrats of 10 by $10 \mathrm{~m}$ were used for measuring trees $>20 \mathrm{~cm} \mathrm{dbh}$, and for poles with diameter $10-20 \mathrm{~cm}$; 5 by $5 \mathrm{~m}$ for saplings with height taller than $1.5 \mathrm{~m}$ and diameter less than $10 \mathrm{~cm}$; and 1 by $1 \mathrm{~m}$ quadrats for seedlings with height less than $1.5 \mathrm{~m}$. For trees and poles the number of individual plants for each species and diameter class was recorded, for saplings and seedlings only the species. Herbarium specimens were collected for identification at Herbarium Bogoriense, Bogor. Vegetation structure was determined by species importance value index (IVI, Mueller-Dumbois \& Ellenberg 1974); Pielou's evenness index (Odum 1971), Margalef's species richness (Odum 1971), Shannon/Wiener species diversity (Odum 1971); and similarity index using Sǿrensen formula (Mueller-Dumbois \& Ellenberg 1974). Canonical correspondence analysis was analyzed using the statistical package MSV 3.1.

\section{RESULTS}

\section{Soil properties, arbuscular mycorrhizal fungi,} and phosphate solubilizing bacteria

A comparison of soil properties (Table 1 ) shows that sand fraction in forest at $0-20 \mathrm{~cm}$ and $20-40 \mathrm{~cm}$ depth $(78$ and $66 \%$ ) and abandoned farmland (47 and $48 \%$ ) was less than in the four tin-mined lands (80-97\%). Except for the 11-year old tin-mined land, $\mathrm{C} / \mathrm{N}$ ratio of tin-mined lands was higher than forest and abandoned farmland. The concentration of $\mathrm{P}_{2} \mathrm{O}_{5}, \mathrm{~K}_{2} \mathrm{O}, \mathrm{K}$, and $\mathrm{Na}$ of undisturbed land generally was higher than of disturbed land, and gradually decreases along with the newly abandoned tin-mined land. The cation-exchange capacity (CEC) of all tin-mined lands was very low (0.4-3.9). The concentrations of other soil properties showed different relations to each of tin-mined lands.

Table 1 Soil properties of study sites.

\begin{tabular}{|c|c|c|c|c|c|c|c|c|c|c|c|c|c|c|c|c|c|c|}
\hline \multirow{4}{*}{ Study sites } & \multirow{3}{*}{ 爰 } & \multirow{3}{*}{$\begin{array}{l}\text { 만 } \\
\text { 쥬 } \\
\text { ஸे }\end{array}$} & \multicolumn{2}{|l|}{ Texture } & \multirow{4}{*}{$\begin{array}{c}\mathrm{pH} \\
\mathrm{H}_{2} \mathrm{O}\end{array}$} & \multicolumn{3}{|c|}{ Soil organic matter } & \multicolumn{2}{|c|}{$\mathrm{HCl} 25 \%$} & \multicolumn{7}{|c|}{ Cation-exchange } & \multirow{3}{*}{$\begin{array}{c}z \\
\check{z} \\
\grave{Y} \\
\mathrm{Al}^{3+}\end{array}$} \\
\hline & & & \multirow{2}{*}{ 䓂 } & \multirow{2}{*}{$\frac{\vec{\pi}}{U}$} & & \multirow{2}{*}{ 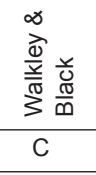 } & \multirow{2}{*}{$\begin{array}{l}\frac{\bar{c}}{\frac{\pi}{0}} \\
\frac{0}{0} \\
\frac{1}{1} \\
N\end{array}$} & \multirow{3}{*}{$\mathrm{C} / \mathrm{N}$} & \multirow{2}{*}{$O^{\infty}$} & \multirow{2}{*}{$O_{x^{N}}$} & \multicolumn{7}{|c|}{ (NH4 - Acetate $1 \mathrm{~N}, \mathrm{pH} 7)$} & \\
\hline & & & & & & & & & & & $\mathrm{Ca}$ & $\mathrm{Mg}$ & $\mathrm{K}$ & $\mathrm{Na}$ & Total & CEC & $B$ & \\
\hline & $\mathrm{cm}$ & \multicolumn{3}{|c|}{$\%$} & & \multicolumn{2}{|c|}{$\%$} & & \multicolumn{2}{|c|}{$\mathrm{mg} / 100 \mathrm{~g}$} & \multicolumn{6}{|c|}{$\mathrm{cmol}(+) / \mathrm{kg}$} & $\%$ & $\begin{array}{l}\mathrm{cmol} \\
(+) / \mathrm{kg}\end{array}$ \\
\hline \multirow[t]{2}{*}{ Forest } & $0-20$ & 78 & 13 & 10 & 4.7 & 1.6 & 0.2 & 10 & 22 & 5 & 0.2 & 0.1 & 0.1 & 0.1 & 0.4 & 5.8 & 7 & 2.0 \\
\hline & $20-40$ & 66 & 18 & 16 & 4.7 & 1.2 & 0.1 & 14 & 20 & 5 & 0.1 & 0.1 & 0.1 & 0.1 & 0.4 & 5.2 & 7 & 2.0 \\
\hline \multirow{2}{*}{$\begin{array}{l}\text { Abandoned } \\
\text { farmed-land }\end{array}$} & $0-20$ & 47 & 22 & 31 & 4.5 & 3.2 & 0.3 & 12 & 35 & 8 & 0.3 & 0.2 & 0.1 & 0.0 & 0.7 & 14.7 & 4 & 4.8 \\
\hline & $20-40$ & 48 & 22 & 31 & 4.6 & 1.7 & 0.1 & 12 & 36 & 7 & 0.3 & 0.2 & 0.1 & 0.1 & 0.6 & 9.6 & 6 & 3.7 \\
\hline \multirow{2}{*}{$\begin{array}{l}\text { Tin-mined } \\
\text { land } 38 \text { yrs }\end{array}$} & $0-20$ & 96 & 2 & 2 & 5.1 & 0.3 & 0.0 & 14 & 5 & 2 & 0.2 & 0.1 & 0.0 & 0.1 & 0.4 & 1.0 & 40 & 0.2 \\
\hline & $20-40$ & 95 & 2 & 3 & 5.0 & 0.2 & 0.0 & 10 & 4 & 2 & 0.1 & 0.1 & 0.0 & 0.1 & 0.3 & 0.9 & 31 & 0.2 \\
\hline $\begin{array}{l}\text { Tin-mined land } \\
\text { land } 11 \mathrm{yrs}\end{array}$ & $0-20$ & 83 & 5 & 13 & 4.9 & 0.2 & 0.0 & 10 & 11 & 4 & 0.2 & 0.1 & 0.0 & 0.0 & 0.3 & 2.0 & 28 & 0.9 \\
\hline \multirow{2}{*}{$\begin{array}{l}\text { Tin-mined land } \\
\text { land } 7 \text { yrs }\end{array}$} & $0-20$ & 94 & 4 & 3 & 4.8 & 1.0 & 0.1 & 13 & 49 & 3 & 0.2 & 0.1 & 0.0 & 0.1 & 0.3 & 3.3 & 16 & 0.6 \\
\hline & $20-40$ & 93 & 6 & 2 & 4.8 & 1.2 & 0.1 & 14 & 71 & 3 & 0.2 & 0.1 & 0.0 & 0.1 & 0.4 & 3.9 & 19 & 0.7 \\
\hline \multirow{2}{*}{$\begin{array}{l}\text { Barren tin- } \\
\text { mined land }\end{array}$} & $0-20$ & 94 & 2 & 4 & 4.8 & 0.2 & 0.0 & 15 & 2 & 3 & 0.1 & 0.2 & 0.0 & 0.0 & 0.3 & 0.4 & 73 & 0.3 \\
\hline & $20-40$ & 97 & 1 & 2 & 4.5 & 0.1 & 0.0 & 13 & 3 & 3 & 0.3 & 0.2 & 0.0 & 0.0 & 0.6 & 1.4 & 40 & 0.1 \\
\hline
\end{tabular}

Table 2 Status of phosphate solubilizing bacteria (PSB) and arbuscular mycorrhizal fungi (AMF) in study sites.

\begin{tabular}{|c|c|c|c|c|c|c|}
\hline Study site & Dominant vegetation & Depth $(\mathrm{cm})$ & $\begin{array}{l}\text { Total average of PSB } \\
\text { colonies (105 / g soil/ } \\
\text { dominant plant species) }\end{array}$ & $\begin{array}{l}\text { Total average of AMF } \\
\text { spores ( } / 50 \mathrm{~g} \text { soil / } \\
\text { dominant plant species) }\end{array}$ & $\begin{array}{l}\text { No. of AMF } \\
\text { genera }\end{array}$ & $\begin{array}{l}\text { Dominant AMF } \\
\text { genus }\end{array}$ \\
\hline Forest & $\begin{array}{l}\text { Tristaniopsis whiteana } \\
\text { Syzygium sp. } \\
\text { Ilex cymosa }\end{array}$ & $0-20$ & 4.4 & 15.0 & 4 & $\begin{array}{l}\text { Glomus } \\
57 \%\end{array}$ \\
\hline $\begin{array}{l}\text { Abandoned } \\
\text { farmed-land }\end{array}$ & $\begin{array}{l}\text { Trema orientalis } \\
\text { Melastoma malabathricum } \\
\text { Pternandra galeata }\end{array}$ & $0-20$ & 12.7 & 45.3 & 5 & $\begin{array}{l}\text { Glomus } \\
44 \%\end{array}$ \\
\hline $\begin{array}{l}\text { Tin-mined } \\
\text { land } 38 \text { yrs }\end{array}$ & $\begin{array}{l}\text { Rhodomyrtus tomentosa } \\
\text { Eriachne pallescens } \\
\text { Ischaemum sp. }\end{array}$ & $0-20$ & 1.3 & 261.7 & 5 & $\begin{array}{l}\text { Glomus } \\
95 \%\end{array}$ \\
\hline $\begin{array}{l}\text { Tin-mined } \\
\text { land } 11 \text { yrs }\end{array}$ & $\begin{array}{l}\text { Paspalum orbiculare } \\
\text { Blumea balsamifera } \\
\text { Melastoma malabathricum }\end{array}$ & $0-20$ & 4.2 & 57.0 & 4 & $\begin{array}{l}\text { Glomus } \\
59 \%\end{array}$ \\
\hline $\begin{array}{l}\text { Tin-mined } \\
\text { land } 7 \text { yrs }\end{array}$ & $\begin{array}{l}\text { Fymbristylis pauciflora } \\
\text { Trema orientalis } \\
\text { Melastoma malabathricum }\end{array}$ & $0-20$ & 6.2 & 47.0 & 5 & $\begin{array}{l}\text { Glomus } \\
67 \%\end{array}$ \\
\hline $\begin{array}{l}\text { Barren tin-mined } \\
\text { land } 0 \text { yrs }\end{array}$ & --_- & $0-20$ & 6.0 & 2.0 & 1 & $\begin{array}{l}\text { Glomus } \\
100 \%\end{array}$ \\
\hline
\end{tabular}


Table 3 Number of individuals, species, and families in study sites, per growth phase.

\begin{tabular}{|c|c|c|c|c|c|c|c|c|c|c|c|c|c|c|c|}
\hline \multirow[b]{2}{*}{ Study site } & \multicolumn{5}{|c|}{ Number of individuals / ha } & \multicolumn{5}{|c|}{ Number of species } & \multicolumn{5}{|c|}{ Number of families } \\
\hline & $\begin{array}{l}\text { seed } \\
\text { lings }\end{array}$ & $\begin{array}{l}\text { sap } \\
\text { lings }\end{array}$ & poles & trees & total & $\begin{array}{l}\text { seed } \\
\text { lings }\end{array}$ & $\begin{array}{l}\text { sap } \\
\text { lings }\end{array}$ & poles & trees & total & $\begin{array}{l}\text { seed } \\
\text { lings }\end{array}$ & $\begin{array}{l}\text { sap } \\
\text { lings }\end{array}$ & poles & trees & total \\
\hline Forest & 2,665 & 4,155 & 305 & 170 & 7,295 & 42 & 66 & 24 & 11 & 85 & 24 & 30 & 14 & 8 & 44 \\
\hline $\begin{array}{l}\text { Abandoned } \\
\text { farmed-land }\end{array}$ & 1,640 & 5,495 & 40 & 0 & 7,175 & 48 & 47 & 4 & 0 & 71 & 27 & 25 & 4 & 0 & 38 \\
\hline $\begin{array}{l}\text { Tin-mined } \\
\text { land } 38 \text { yrs }\end{array}$ & 2,125 & 55 & 0 & 0 & 2,180 & 15 & 1 & 0 & 0 & 16 & 12 & 1 & 0 & 0 & 13 \\
\hline $\begin{array}{l}\text { Tin-mined } \\
\text { land } 11 \text { yrs }\end{array}$ & 1,675 & 45 & 0 & 0 & 1,720 & 7 & 2 & 0 & 0 & 8 & 4 & 2 & 0 & 0 & 5 \\
\hline $\begin{array}{l}\text { Tin-mined } \\
\text { land } 7 \text { yrs }\end{array}$ & 890 & 0 & 0 & 0 & 890 & 6 & 0 & 0 & 0 & 6 & 4 & 0 & 0 & 0 & 4 \\
\hline $\begin{array}{l}\text { Barren tin-mined } \\
\text { land } 0 \mathrm{yrs}\end{array}$ & 0 & 0 & 0 & 0 & 0 & 0 & 0 & 0 & 0 & 0 & 0 & 0 & 0 & 0 & 0 \\
\hline
\end{tabular}

Table 4 Similarity indices between different study site, per growth phase.

\begin{tabular}{|c|c|c|c|c|c|}
\hline \multirow[t]{2}{*}{ Study sites } & & \multicolumn{4}{|c|}{ Growth phases } \\
\hline & & Seedling & Sapling & Pole & Tree \\
\hline \multirow[t]{5}{*}{0 -year old tin-mined land } & 7-year old tin-mined land & 0 & 0 & 0 & 0 \\
\hline & 11-year old tin-mined land & 0 & 0 & 0 & 0 \\
\hline & 38-year old tin-mined land & 0 & 0 & 0 & 0 \\
\hline & abandoned farmed-land & 0 & 0 & 0 & 0 \\
\hline & forest & 0 & 0 & 0 & 0 \\
\hline \multirow[t]{4}{*}{ 7-year old tin-mined land } & 11-year old tin-mined land & 27.8 & 0 & 0 & 0 \\
\hline & 38-year old tin-mined land & 18.6 & 0 & 0 & 0 \\
\hline & abandoned farmed-land & 17.6 & 0 & 0 & 0 \\
\hline & forest & 0 & 0 & 0 & 0 \\
\hline \multirow[t]{3}{*}{ 11-year old tin-mined land } & 38-year old tin-mined land & 15.4 & 0 & 0 & 0 \\
\hline & abandoned farmed-land & 16.9 & 0 & 0 & 0 \\
\hline & forest & 0 & 0 & 0 & 0 \\
\hline \multirow[t]{2}{*}{ 38-year old tin-mined land } & abandoned farmed-land & 19.9 & 0 & 0 & 0 \\
\hline & forest & 1.5 & 0 & 0 & 0 \\
\hline Abandoned farmed-land & forest & 13.7 & 25.0 & 2.0 & 0 \\
\hline
\end{tabular}

Table 2 shows the development of some microbiological parameters. The average number of arbuscular mycorrhizal fungi (AMF) spores per $50 \mathrm{~g}$ soil per dominant plant species in 0-20 $\mathrm{cm}$ in forest soil (15.0) was less than that of abandoned farmland (45.3) and the number of spores in 38-year old tin-mined land was the highest (261.7). The number of AMF spores increases strongly with the period of abandonment of tin-mined land, with lowest values in 0-year old barren tin-mined land. The number of genera was between three and five, and Glomus Tul. \& C.Tul. (Glomaceae) was dominant (44-100\%). In contrast to AMF, the average number of phosphate solubilizing bacteria (PSB) in tin-mined lands showed a slight increase at 7 years, and a gradual decrease after that. The average number of PSB per $\mathrm{g}$ soil in $0-20 \mathrm{~cm}$ in forest soil $\left(4.410^{5}\right)$ was less than that of abandoned farmland $\left(12.710^{5}\right)$ and the smallest number of spores was found in 38-year old tin-mined land $\left(1.310^{5}\right)$.

\section{Floristic composition}

The number of individuals, species, and families was highest in riparian forest, and gradually decreased in abandoned farmland, 38-year old tin-mined land, 11-year old tin-mined land, 7-year old tin-mined land (Table 3 ). Trees (11 species) and poles were only found in forest (24 species) and abandoned farmland (4 species). Saplings were found at all study sites except on the 7-year old tin-mined land. Similarities between study sites with different regeneration phases could be assessed only on basis of seedlings (Table 4), and show that similarity is generally low (less than $28 \%$ ), and that the similarity index (seedlings) of the oldest tin-mined land and that of riparian forest is still only $1.5 \%$.

A comparison of the development of structural properties and diversity of the vegetation is presented in Table 5.

\section{Species composition (see Appendix)}

Species composition (measured by Importance value index, IVI) for all stages of plant development differs between all study sites. Gaertnera vaginata (Rubiaceae), Calophyllum pulcherrimum (Clusiaceae), Calophyllum lanigerum, Syzygium lineatum (Myrtaceae), and Garcinia parvifolia (Clusiaceae) have the five highest seedling IVIs in secondary riparian forest; Scleria levis (Cyperaceae), Trema orientalis (Ulmaceae), Dicranopteris linearis (Gleicheniaceae), Melastoma malabathricum (Melastomataceae), and Paspalum conjugatum (Poaceae) on abandoned farmland; Rhodomyrtus tomentosa (Myrtaceae), Eriachne pallescens (Poaceae), Ischaemum sp. (Poaceae), Crotalaria sp. (Fabaceae), and Melastoma malabathricum on 38-year old tin-mined land; Blumea balsamifera (Asteraceae), Paspalum conjugatum, Imperata cylindrica (Poaceae), Fimbristylis pauciflora (Cyperaceae), Melastoma malabathricum on 11-year old tin-mined land; Fimbristylis pauciflora, Imperata 
Table 5 Structure indices for study sites, per growth phase.

\begin{tabular}{|c|c|c|c|c|c|c|c|}
\hline \multirow[b]{2}{*}{$\begin{array}{l}\text { Growth } \\
\text { phases }\end{array}$} & \multirow[b]{2}{*}{ Indices } & \multicolumn{6}{|c|}{ Study sites } \\
\hline & & $\begin{array}{l}0 \text {-year old } \\
\text { tin-mined land }\end{array}$ & $\begin{array}{l}\text { 7-year old } \\
\text { tin-mined land }\end{array}$ & $\begin{array}{l}11 \text {-year old } \\
\text { tin-mined land }\end{array}$ & $\begin{array}{l}\text { 38-year old } \\
\text { tin-mined land }\end{array}$ & $\begin{array}{l}\text { Abandoned } \\
\text { farmed-land }\end{array}$ & Forest \\
\hline \multirow[t]{4}{*}{ Seedling } & Dominance $(c)$ & 0 & 0.23 & 0.36 & 0.09 & 0.05 & 0.06 \\
\hline & Species richness $(d)$ & 0 & 2.22 & 2.38 & 5.33 & 18.68 & 15.04 \\
\hline & Evenness $(e)$ & 0 & 0.79 & 0.55 & 0.90 & 0.82 & 0.77 \\
\hline & Shannon Wiener (_) & 0 & 0.61 & 0.46 & 1.06 & 1.37 & 1.25 \\
\hline \multirow[t]{4}{*}{ Sapling } & Dominance $(c)$ & 0 & 0 & 0.65 & 1.00 & 0.05 & 0.03 \\
\hline & Species richness $(d)$ & 0 & 0 & 1.05 & 0 & 15.13 & 22.26 \\
\hline & Evenness $(e)$ & 0 & 0 & 0.05 & 0 & 0.77 & 0.82 \\
\hline & Shannon Wiener (_) & 0 & 0 & 0.15 & 0 & 1.28 & 1.50 \\
\hline \multirow[t]{4}{*}{ Pole } & Dominance $(c)$ & 0 & 0 & 0 & 0 & 0.48 & 0.12 \\
\hline & Species richness $(d)$ & 0 & 0 & 0 & 0 & 4.43 & 12.88 \\
\hline & Evenness $(e)$ & 0 & 0 & 0 & 0 & 0.77 & 0.84 \\
\hline & Shannon Wiener (_) & 0 & 0 & 0 & 0 & 0.47 & 1.16 \\
\hline \multirow[t]{4}{*}{ Tree } & Dominance $(c)$ & 0 & 0 & 0 & 0 & 0 & 0.15 \\
\hline & Species richness $(d)$ & 0 & 0 & 0 & 0 & 0 & 6.53 \\
\hline & Evenness $(e)$ & 0 & 0 & 0 & 0 & 0 & 0.87 \\
\hline & Shannon Wiener (_) & 0 & 0 & 0 & 0 & 0 & 0.91 \\
\hline
\end{tabular}

cylindrica, Melastoma malabathricum, Eupatorium inulaefolium (Asteraceae), Paspalum orbiculare on 7-year old tin-mined land. No seedlings have been recorded on 0 -year old tin-mined land.

Similarly, each study site had different sapling species. Calophyllum lanigerum, Pternandra galeata (Melastomataceae), Tristaniopsis whiteana (Myrtaceae), Syzygium lineatum, and Rhodamnia cinerea (Myrtaceae) were the five highest sapling IVIs in secondary riparian forest.

Trema orientalis, Pternandra galeata, Gynotroches axillaris (Rhizophoraceae), Adinandra dumosa (Theaceae) and Schima wallichii were the five highest sapling IVIs on abandoned farmland. One species of Myrtaceae was the only sapling found on 38-year old tin-mined land. Commersonia bartramia (Sterculiaceae) was the only sapling found on 11-year old tin-mined land, and no saplings were recorded on 7-year and 0-year old tin-mined lands. Ilex cymosa (Aquifoliaceae), Calophyllum pulcherrimum, Adinandra dumosa, Tristaniopsis whiteana, and Syzygium lineatum were the five highest pole IVIs in secondary riparian forest. Syzygium sp.6 (Myrtaceae), Sapium baccatum (Euphorbiaceae), and Artocarpus integer (Moraceae) were the only poles on abandoned farmland, and no poles were found on tin-mined land of any age. Trees were only found in riparian forest and the five highest IVIs were: Schima wallichii, Tristaniopsis whiteana, Ilex cymosa, Syzygium lineatum, and Cratoxylum formosum (Clusiaceae).

\section{DISCUSSION}

It appears that the combination of high sand component, and low macronutrients, CEC, and soil organic matter in the tinmined lands determine the floristic composition and species composition. Older tin-mined lands were shown to be more fertile than younger ones, and to be richer floristically and in species composition. From the PSB and AMF point of view, it appears that the presence of PSB in tin-mined lands reflects phosphate concentration availability in soil. In contrast to PSB, the number of AMF spores in tin-mined lands was likely supported by the soil fertility and its vegetation development above ground. As the availability of phosphate in the soil is low, root hairs and spore production seemed to increase. In general, with increasing soil fertility, PSB population increased while the number of AMF spores tended to decrease. The severe conditions in barren tin-mined land supported only one Glomus species.
Concentration and distribution of species in disturbed study sites was higher than for undisturbed sites because the number of species and the number of plants at disturbed sites were less. Therefore, the species richness of disturbed sites was poorer than for undisturbed sites. The floristic composition of older abandoned tin-mined lands is gradually more similar to the site with forest, but, similarity of forest to 38-year old tin-mined land is still low. The high dissimilarity among study sites confirms that succession takes a long time and supports the projection in Singkep Island (Elfis 1998).

Succession is initiated by herb species, followed by shrub species, but the time required for poles and finally trees to appear apparently exceeds the 38 years covered in this study. The slow succession reflects the long period of time needed to increase soil fertility, accumulate organic material and so improve the quality of the soils' microclimate. During this time, apparently also minerals are added, reducing the sand and increasing the silt and clay component. Much older tin-mined lands are needed to present a more comprehensive conclusion. Unfortunately, illegal mining and illegal re-mining in revegetated tinmined lands (Bangka Pos 2004) make these difficult to find.

To accelerate succession, potential species candidates can be identified, starting with herb species belonging to Cyperaceae and Poaceae, or shrub species belonging to Melastomataceae and Myrtaceae.

Acknowledgements The author gratefully acknowledges the funding of this research by ITTO (International Tropical Timber Organization) (039/03A). I thank Directorate General of Higher Education, Ministry of Education, Republic of Indonesia, and the government of Bangka Belitung Province for partially funding the field research. I also thank Bapak Suanta, Robby, Wistria, Sinem, and Bambang who helped me in the field. I offer special thank to Bapak Zainal Fanani for his help in identifying almost all specimens, and Bapak Edi Mirmanto whom the author consulted for statistical analysis. Special thanks are also due to Dr. Campbell Webb and Dr. Ruth Kiew for their comments on the manuscript.

\section{REFERENCES}

Ang LH. 1994. Problems and prospects of afforestation on sand tin tailings in Peninsular Malaysia. Journal of Tropical Forest Science 7: 87-105. ASTIRA - Asosiasi Tambang Timah Rakyat. 2005. Tambang Rakyat Potensi Terabaikan.

Bakosurtanal - Badan Koordinasi Survei dan Pemetaan Nasional. 1986. Peta Land System Sumatera. Skala $1: 250.000$

Bangka Pos 2004. 65 Persen Reklamasi PT Timah Rusak Berat. Bangka Pos 19 Maret 2004. 
CSM-BGBD - Conservation Sustainable Management - Below Ground Biodiversity Project Indonesia. 2004. Brief protocols for soil biota inventory (Project Doc. No 4).

Elfis. 1998. Vegetasi kerangas pada daerah bekas penambangan timah di Pulau Singkep Kepulauan Riau [tesis]. Universitas Andalas, Program Pascasarjana, Padang.

Gadermann JW, Nicolson TH. 1963. Spores of endogone species extracted from soil by wet sieving and decanting. Transactions of the British Mycological Society 46: 235-244.

Lamb D, Tomlinson M. 1994. Forest rehabilitation in the Asia-Pasific Region: Past lessons and present uncertainties. Journal of Tropical Forest Science 7: 157-170.

MacKinnon K, Hatta G, Halim H, MangalikA. 1996. The ecology of Kalimantan: Indonesian Borneo. Periplus Editions (HK) Ltd., Singapore.

Mitchell BA. 1959. The ecology of tin mine spoil heaps. Part I. Sand and gravel tailings. Malayan Forester 22: 111-132.

Mueller-Dumbois D, Ellenberg H. 1974. Aims and methods of vegetation ecology. Wiley \& Sons, New York.

Nurtjahya E. 2001. Revegetation on tin post mining area in Bangka Island (Bibliographical Review). Indonesian Mining Journal 7, 3: 32-37.

Odum EP. 1971. Fundamentals of ecology, 3rd ed. Saunders \& Co., Philadelphia.

PT Tambang Timah 2004. Peta Ikhtisar Penambangan Timah di Pulau Bangka.
Sambas EN, Suhardjono. 1995. Dampak dan usaha rehabilitasi bekas tambang timah di Kabupaten Bangka. In: Prawiroatmodjo S (ed), Penelitian dan pengembangan model reklamasi lahan terdegradasi. Laporan Teknik 1994-1995. Pusat Penelitian dan Pengembangan Biologi, LIPI, Bogor: 74-81.

Schenck NC, Perez Y. 1988. Manual for the identification of va mycorrhizal fungi. 2nd ed. International Culture Collection of VA Mycorrhizal Fungi, Gainesville.

Setiadi D, Muhadiono I. 2001. Penuntun praktikum ekologi. Laboratorium Ekologi, Institut Pertanian Bogor, Bogor.

Setyorini D, Adiningsih JS, Rochayati S. 2003. Uji tanah sebagai dasar penyusunan rekomendasi pemupukan. Balai Penelitian Tanah. Pusat Penelitian dan Pengembangan Tanah dan Agroklimat, Bogor.

Soerianegara I, Indrawan A. 1995. Ekologi hutan Indonesia. Laboratorium Ekologi Hutan, Fakultas Kehutanan, Institut Pertanian Bogor, Bogor.

Van Steenis CGGJ. 1932. Botanical results of a trip to the Anambas and Natoena Islands. Bulletin du Jardin Botanique de Buitenzorg, ser. III, 13: $151-211$.

Whitten AJ, Damanik SJ, Anwar J, Hisyam N. 2000. The ecology of Sumatra. Periplus Editions (HK) Ltd., Singapore.

Widagdo V, Suwandi, Miskad S, Dedin K, Suratman, Hapid H, Dai J, Hidayat A, Buurman P, Balsem T. 1990. Buku keterangan peta satuan lahan dan tanah Pulau Bangka dan sebagian Sumatera daratan (lembar 1113, 1114 1212, dan 1213). Pusat Penelitian Tanah dan Agroklimat, Bogor.

Appendix 1 Floristic composition and Importance value index of 0-year, 7-year, 11-year, 38-year, abandoned farmed land, and forest.

\begin{tabular}{|c|c|c|c|c|c|c|}
\hline Species & Family & 7-year & 11-year & 38-year & Farmed-land & Forest \\
\hline \multicolumn{7}{|l|}{ Seedlings } \\
\hline Adinandra dumosa Jack & Theaceae & & & & 4.05 & \\
\hline Ancistrocladus tectorius Merr. & Ancistrocladaceae & & & & & 4.35 \\
\hline Anonim sp.1 & Orchidaceae & & & & 4.73 & \\
\hline Anonim sp.2 & & & & & 1.45 & \\
\hline Anonim sp.3 & & & & 15.66 & & \\
\hline Anonim sp.4 & & & & & & 1.18 \\
\hline Anonim sp.11 & Orchidaceae & & & & & 0.99 \\
\hline Anonim sp.12 & Araceae & & & & & 1.37 \\
\hline Anonim sp.13 & & & & & & 1.18 \\
\hline Anonim sp.14 & Arecaceae & & & & & 1.99 \\
\hline Aporosa cf. aurita (Tul.) Miq. & Euphorbiaceae & & & & 1.15 & 1.18 \\
\hline Archidendron clypearia (Jack) Nielsen & Fabaceae & & & & 3.21 & \\
\hline Archidendron microcarpum (Benth.) Nielsen & Fabaceae & & & & 1.15 & \\
\hline Artabotrys suaveolens Blume & Annonaceae & & & & & 2.18 \\
\hline Arthrophyllum diversifolium Blume & Araliaceae & & & & & 0.99 \\
\hline Blumea balsamifera (L.) DC. & Asteraceae & & 111.51 & & & \\
\hline Calamus sp. & Arecaceae & & & & & 8.03 \\
\hline Calophyllum lanigerum Miq. & Clusiaceae & & & & 4.05 & 13.26 \\
\hline Calophyllum pulcherrimum Wall. ex Choisy & Clusiaceae & & & & 2.60 & 18.68 \\
\hline Chaetocarpus castanocarpus (Roxb.) Thwaites & Euphorbiaceae & & & & & 3.55 \\
\hline Chionanthus ramiflorus Roxb. & Oleaceae & & & & 3.81 & 1.18 \\
\hline Commersonia bartramia (L.) Merr. & Sterculiaceae & & & & 1.15 & \\
\hline Cratoxylum glaucum Korth. & Clusiaceae & & & & 1.15 & \\
\hline Crotalaria sp. & Leguminosae & & & 17.17 & & \\
\hline Daphniphyllum laurinum (Benth.) Baill. & Daphniphyllaceae & & & & 1.15 & \\
\hline Dianella nemorosa Lam. & Liliaceae & & & & 5.50 & \\
\hline Dicranopteris linearis (Burm.f.) Underw. & Gleicheniaceae & & & & 14.87 & \\
\hline Dillenia suffruticosa (Griff.) Martelli & Dilleniaceae & & & 4.64 & & \\
\hline Dioscorea alata L. & Dioscoreaceae & & & & 1.45 & \\
\hline Eragrostis chariis (Schult.) Hitchc. & Poaceae & & 7.75 & & & \\
\hline Eriachne pallescens $\mathrm{R} . \mathrm{Br}$. & Poaceae & & & 20.47 & & \\
\hline Eupatorium inulaefolium Humb., Bonpl. \& Kunth & Asteraceae & 19.64 & & 7.12 & 6.95 & \\
\hline Eurya acuminata DC. & Theaceae & & & & 1.15 & 4.11 \\
\hline Fimbristylis pauciflora R.Br. & Cyperaceae & 66.82 & 14.31 & 14.22 & & \\
\hline Freycinettia sp. & Pandanaceae & & & & & 5.55 \\
\hline Gaertnera vaginata Poir. & Rubiaceae & & & & 2.36 & 31.91 \\
\hline Garcinia parvifolia (Miq.) Miq. & Clusiaceae & & & & & 9.23 \\
\hline Glechenia sp. & Gleicheniaceae & & & 12.33 & & \\
\hline Guioa pubescens (Zoll. \& Moritzi) Radlk. & Sapindaceae & & & & & 1.37 \\
\hline Gynotroches axillaris Blume & Rhizophoraceae & & & & & 1.18 \\
\hline Ilex cymosa Blume & Aquifoliaceae & & & & & 0.99 \\
\hline Imperata cylindrica (L.) P.Beauv. & Poaceae & 50.25 & 16.68 & & 4.96 & \\
\hline Ischaemum sp. & Poaceae & & & 18.82 & & \\
\hline Ixora miquelii Bremek. & Rubiaceae & & & & & 4.16 \\
\hline Kibatalia maingayi (Hook.f.) Woodson & Apocynaceae & & & & 1.45 & 3.36 \\
\hline Lepisanthes amoena (Hassk.) Leenh. & Sapindaceae & & & & & 0.99 \\
\hline
\end{tabular}


Appendix 1 (cont.)

\begin{tabular}{|c|c|c|c|c|c|c|c|}
\hline Species & Family & 0-year & 7-year & 11-year & 38-year & Farmed-land & Forest \\
\hline Lithocarpus blumeanus (Korth.) Rehder & Fagaceae & & & & & & 0.99 \\
\hline Litsea forstenii Blume & Lauraceae & & & & & & 8.40 \\
\hline Litsea umbellata (Lour.) Merr. & Lauraceae & & & & & 1.15 & \\
\hline Lycopodium cernuum $\mathrm{L}$. & Lycopodiaceae & & & & & 12.13 & \\
\hline Macaranga javanica (Blume) Müll.Arg. & Euphorbiaceae & & & & & 4.89 & \\
\hline Macaranga trichocarpa (Rchb.f. \& Zoll.) Müll.Arg. & Euphorbiaceae & & & & & 1.15 & \\
\hline Mallotus paniculatus (Lam.) Müll.Arg. & Euphorbiaceae & & & & & 1.15 & \\
\hline Melastoma malabatricum L. & Melastomataceae & & 37.75 & 12.21 & 15.86 & 14.04 & \\
\hline Mussaenda frondosa $\mathrm{L}$. & Rubiaceae & & & & & 4.05 & 0.99 \\
\hline Nephelium mangayi Hiern & Sapindaceae & & & & & & 0.99 \\
\hline Nephenthes sp.1 & Nephentaceae & & & & 3.09 & & \\
\hline Nephenthes sp.2 & Nephentaceae & & & & & 6.41 & \\
\hline Ormosia bancana (Miq.) Merr. & Papilionaceae & & & & & 1.75 & 1.18 \\
\hline Pandanus sp. & Pandanaceae & & & & & & 9.15 \\
\hline Paspalum conjugatum P.J.Bergius & Poaceae & & 12.49 & 33.07 & & 12.14 & \\
\hline Paspalum orbiculare G.Forst. & Poaceae & & 13.05 & & & & \\
\hline Ploiarium alternifolium (Vahl) Melch. & Theaceae & & & & & 1.15 & \\
\hline Pternandra galeata (Korth.) Ridl. & Melastomataceae & & & & & 2.36 & 7.65 \\
\hline Puar hijau & Zingiberaceae & & & & & 1.45 & \\
\hline Rhodamnia cinerea Jack & Myrtaceae & & & & & & 4.73 \\
\hline Rhodomyrtus tomentosa (Aiton) Hassk. & Myrtaceae & & & & 36.87 & & \\
\hline Sapium baccatum Roxb. & Euphorbiaceae & & & & & 1.15 & \\
\hline Schima wallichii (DC.) Korth. & Theaceae & & & & 7.73 & 1.45 & 2.98 \\
\hline Scleria levis Retz. & Cyperaceae & & & 4.47 & 10.89 & 23.12 & \\
\hline Stenochlaena palustris (Burm.f.) Bedd. & Stenochlaenaceae & & & & & 2.29 & \\
\hline Symplocos cochinchinensis (Lour.) S.Moore & Symplocaceae & & & & & & 2.55 \\
\hline Syzygium claviflorum (Roxb.) Wall. ex A.M.Cowan \& Cowan & Myrtaceae & & & & & 4.35 & 3.98 \\
\hline Syzygium lineatum (DC.) Merr. \& L.M.Perry & Myrtaceae & & & & & 1.15 & 12.46 \\
\hline Syzygium sp.2 & Myrtaceae & & & & & 2.90 & \\
\hline Syzygium sp.6 & Myrtaceae & & & & & 1.45 & \\
\hline Syzygium zeylanicum (L.) DC. & Myrtaceae & & & & & 2.29 & 0.99 \\
\hline Taenitis blechnoides (Willd.) Sw. & Taenitidaceae & & & & & & 5.42 \\
\hline Tarrena fragrans (Blume) Koord. \& Valeton & Rubiaceae & & & & & & 2.87 \\
\hline Timonius flavescens (Jack) Baker & Rubiaceae & & & & & 1.75 & \\
\hline Trema orientalis (L.) Blume & Ulmaceae & & & & 6.55 & 19.07 & \\
\hline Tristaniopsis whiteana (Griff.) Peter G.Wilson \& J.T.Waterh. & Myrtaceae & & & & & & 1.37 \\
\hline Urceola brachysepala Hook. f. & Apocynaceae & & & & & 1.45 & 3.49 \\
\hline Vernonia arborea Ham. & Asteraceae & & & & & 3.21 & \\
\hline Vitex pinnata L. & Verbenaceae & & & & 8.57 & & \\
\hline \multicolumn{8}{|l|}{ Saplings } \\
\hline Adinandra dumosa Jack & Theaceae & & & & & 10.13 & 0.67 \\
\hline Anonim sp.5 & & & & & & & 0.43 \\
\hline Anonim sp.6 & Arecaceae & & & & & & 1.58 \\
\hline Anonim sp.9 & & & & & & & 0.43 \\
\hline Anonim sp.15 & & & & & & & 0.86 \\
\hline Anonim sp.16 & & & & & & & 1.29 \\
\hline Anonim sp.17 & Myrtaceae & & & & 200.0 & & \\
\hline Aporosa cf. aurita (Tul.) Miq. & Euphorbiaceae & & & & & 5.90 & 3.81 \\
\hline Archidendron clypearia (Jack) Nielsen & Fabaceae & & & & & 2.46 & \\
\hline Arthrophyllum diversifolium Blume & Araliaceae & & & & & & 0.43 \\
\hline Artocarpus sp. & Moraceae & & & & & & 0.67 \\
\hline Baccaurea bracteata Müll.Arg. & Euphorbiaceae & & & & & 0.57 & 0.98 \\
\hline Brackenridgea palustris Bartell. & Ochnaceae & & & & & & 0.43 \\
\hline Brucea javanica (L.) Merr. & Simaroubaceae & & & & & 0.57 & \\
\hline Calophyllum lanigerum Miq. & Clusiaceae & & & & & & 14.43 \\
\hline Calophyllum pulcherrimum Wall. ex Choisy & Clusiaceae & & & & & 0.57 & 2.95 \\
\hline Chaetocarpus castanocarpus (Roxb.) Thwaites & Euphorbiaceae & & & & & & 6.72 \\
\hline Chionanthus ramiflorus Roxb. & Oleaceae & & & & & & 4.15 \\
\hline Clerodendrum villosum Blume & Verbenaceae & & & & & 0.57 & \\
\hline Commersonia bartramia (L.) Merr. & Sterculiaceae & & & 44.44 & & 5.99 & \\
\hline Cratoxylum formosum Benth. \& Hook.f. ex Dyer & Clusiaceae & & & & & & 0.55 \\
\hline Cratoxylum glaucum Korth. & Clusiaceae & & & & & 1.80 & 0.55 \\
\hline Daphniphyllum laurinum (Benth.) Baill. & Daphniphyllaceae & & & & & 1.32 & 1.10 \\
\hline Decaspermum fruticosum J.R.Forst. \& G.Forst. & Myrtaceae & & & & & 2.91 & \\
\hline Dicranopteris linearis (Burm.f.) Underw. & Gleicheniaceae & & & & & 2.32 & \\
\hline Elaeocarpus mastersii King & Elaeocarpaceae & & & & & & 0.86 \\
\hline Elaeocarpus valetonii Hochr. & Elaeocarpaceae & & & & & 0.57 & 2.40 \\
\hline Eugenia densiflora DC. & Myrtaceae & & & & & 3.96 & 1.72 \\
\hline Eurycoma longifolia Jack & Simaroubaceae & & & & & & 2.45 \\
\hline Ficus consociata Blume & Moraceae & & & & & & 0.43 \\
\hline Ficus grossularioides Burm.f. & Moraceae & & & & & 3.60 & \\
\hline Garcinia parvifolia (Miq.) Miq. & Clusiaceae & & & & & 1.14 & 5.73 \\
\hline Gordonia excelsa Blume & Theaceae & & & & & & 0.43 \\
\hline Gynotroches axillaris Blume & Rhizophoraceae & & & & & 12.04 & 3.93 \\
\hline Helicia serrata (R.Br.) Blume & Proteaceae & & & & & & 2.83 \\
\hline Ilex cymosa Blume & Aquifoliaceae & & & & & 7.95 & 6.75 \\
\hline Kibatalia maingayi (Hook.f.) Woodson & Apocynaceae & & & & & & 0.43 \\
\hline
\end{tabular}


Appendix 1 (cont.)

\begin{tabular}{|c|c|c|c|c|c|c|c|}
\hline Species & Family & 0-year & 7-year & 11-year & 38-year & Farmed-land & Forest \\
\hline Lepisanthes amoena (Hassk.) Leenh. & Sapindaceae & & & & & & 0.43 \\
\hline Lithocarpus blumeanus (Korth.) Rehder & Fagaceae & & & & & & 4.10 \\
\hline Lithocarpus sp.2 & Fagaceae & & & & & & 1.89 \\
\hline Litsea forstenii Blume & Lauraceae & & & & & & 0.43 \\
\hline Litsea umbellata (Lour.) Merr. & Lauraceae & & & & & & 2.71 \\
\hline Lophopetalum javanicum (Zoll.) Turcz. & Celastraceae & & & & & & 0.86 \\
\hline Macaranga javanica (Blume) Müll.Arg. & Euphorbiaceae & & & & & 2.94 & 0.43 \\
\hline Macaranga trichocarpa (Rchb.f. \& Zoll.) Müll.Arg. & Euphorbiaceae & & & & & 1.71 & \\
\hline Mallotus paniculatus (Lam.) Müll.Arg. & Euphorbiaceae & & & & & 0.57 & \\
\hline Melaleuca cajuputi Powell & Myrtaceae & & & & & 3.67 & \\
\hline Ormosia bancana (Miq.) Merr. & Papilionaceae & & & & & & 2.71 \\
\hline Pternandra galeata (Korth.) Ridl. & Melastomataceae & & & & & 14.95 & 14.17 \\
\hline Rhodamnia cinerea Jack & Myrtaceae & & & & & & 7.46 \\
\hline Sapium baccatum Roxb. & Euphorbiaceae & & & & & 0.57 & \\
\hline Schima wallichii (DC.) Korth. & Theaceae & & & & & 9.52 & 2.15 \\
\hline Symplocos cochinchinensis (Lour.) S.Moore & Symplocaceae & & & & & 0.66 & 0.43 \\
\hline Syzygium claviflorum (Roxb.) Wall. ex A.M.Cowan \& Cowan & Myrtaceae & & & & & 4.24 & 6.54 \\
\hline Syzygium sexangulatum (Miq.) Amshoff & Myrtaceae & & & & & & 0.55 \\
\hline Syzygium zeylanicum (L.) DC. & Myrtaceae & & & & & 9.38 & 2.08 \\
\hline Syzygium sp.2 & Myrtaceae & & & & & & 2.64 \\
\hline Syzygium sp.4 & Myrtaceae & & & & & 0.66 & \\
\hline Syzygium sp.5 & Myrtaceae & & & & & 1.02 & \\
\hline Syzygium sp.6 & Myrtaceae & & & & & 4.01 & 3.19 \\
\hline Tarrena fragrans (Blume) Koord. \& Valeton & Rubiaceae & & & & & 2.16 & 3.02 \\
\hline Timonius flavescens (Jack) Baker & Rubiaceae & & & & & 6.38 & 1.53 \\
\hline Trema orientalis (L.) Blume & Ulmaceae & & & & & 16.84 & \\
\hline Tristaniopsis whiteana (Griff.) Peter G.Wilson \& J.T.Waterh. & Myrtaceae & & & & & & 11.81 \\
\hline Vitex pinnata $\mathrm{L}$ & Verbenaceae & & & & & 0.66 & \\
\hline \multicolumn{8}{|l|}{ Poles } \\
\hline Adinandra dumosa Jack & Theaceae & & & & & & 21.72 \\
\hline Artocarpus integer (Thunb.) Merr. & Moraceae & & & & & 27.04 & \\
\hline Calophyllum cf. ferrugineum Ridl. & Clusiaceae & & & & & & 7.33 \\
\hline Calophyllum pulcherrimum Wall. ex Choisy & Clusiaceae & & & & & & 24.02 \\
\hline Chaetocarpus castanocarpus (Roxb.) Thwaites & Euphorbiaceae & & & & & & 13.15 \\
\hline Elaeocarpus mastersii King & Elaeocarpaceae & & & & & & 4.12 \\
\hline Eugenia densiflora DC. & Myrtaceae & & & & & & 5.39 \\
\hline Garcinia parvifolia (Miq.) Miq. & Clusiaceae & & & & & & 7.72 \\
\hline Gynotroches axillaris Blume & Rhizophoraceae & & & & & & 4.49 \\
\hline Ilex cymosa Blume & Aquifoliaceae & & & & & & 89.29 \\
\hline Lophopetalum javanicum (Zoll.) Turcz. & Celastraceae & & & & & & 3.98 \\
\hline Nauclea subdita (Korth.) Steud. & Rubiaceae & & & & & & 4.35 \\
\hline Nephelium eriopetalum Miq. & Sapindaceae & & & & & & 4.79 \\
\hline Pternandra galeata (Korth.) Ridl. & Melastomataceae & & & & & & 8.73 \\
\hline Rhodamnia cinerea Jack & Myrtaceae & & & & & & 4.27 \\
\hline Sapium baccatum Roxb. & Euphorbiaceae & & & & & 30.69 & \\
\hline Schima wallichii (DC.) Korth. & Theaceae & & & & & & 3.95 \\
\hline Symplocos cochinchinensis (Lour.) S.Moore & Symplocaceae & & & & & & 12.16 \\
\hline Syzygium lineatum (DC.) Merr. \& L.M.Perry & Myrtaceae & & & & & & 16.61 \\
\hline Syzygium sp.6 & Myrtaceae & & & & & 41.84 & 6.11 \\
\hline Tristania merguensis Griff. & Myrtaceae & & & & & & 15.65 \\
\hline Tristaniopsis whiteana (Griff.) Peter G.Wilson \& J.T.Waterh. & Myrtaceae & & & & & & 18.15 \\
\hline Vaccinium bancanum Miq. & Ericaceae & & & & & & 10.89 \\
\hline Xanthophyllum vitellinum (Blume) D.Dietr. & Polygalaceae & & & & & & 4.31 \\
\hline \multicolumn{8}{|l|}{ Trees } \\
\hline Calophyllum pulcherrimum Wall. ex Choisy & Clusiaceae & & & & & & 16.98 \\
\hline Cratoxylum formosum Benth. \& Hook.f. ex Dyer & Clusiaceae & & & & & & 20.18 \\
\hline Gluta velutina Blume & Anacardiaceae & & & & & & 7.76 \\
\hline Gordonia excelsa Blume & Theaceae & & & & & & 7.71 \\
\hline Ilex cymosa Blume & Aquifoliaceae & & & & & & 59.76 \\
\hline Ixonanthes petiolaris Blume & Linaceae & & & & & & 8.45 \\
\hline Lithocarpus sp. & Fagaceae & & & & & & 15.00 \\
\hline Lophopetalum javanicum (Zoll.) Turcz. & Celastraceae & & & & & & 9.36 \\
\hline Schima wallichii (DC.) Korth. & Theaceae & & & & & & 65.30 \\
\hline Syzygium lineatum (DC.) Merr. \& L.M.Perry & Myrtaceae & & & & & & 27.51 \\
\hline Tristaniopsis whiteana (Griff.) Peter G.Wilson \& J.T.Waterh. & Myrtaceae & & & & & & 62.01 \\
\hline
\end{tabular}

